\title{
規則相の相分離に伴う歪エネルギー
}

久保

紘*
1. はじめに

金属固溶体中に現われる析出物が歪を伴って生じてい ることはよく知られている. Al 合金中の G.P.ゾーン やクラスターが歪の故に自らその形や析出する結晶学的 な面を決めてしまうのがそのよい例である，同様に固溶 体合金のスピノーダル分解では分解に伴う歪エネルギー が重要な役割を果たしており，系によっては歪のために 分解が押さえられる場合あある(1). これらの現象は固溶 体に限らず，規則合金やセラミックスであ同様であり歪 は相の変化に大きな影響を及ぼしている．しかし後者の 場合には元素が規則的に配列している事に起因する特有 の現象があって, 固溶体での話はそのままでは通用しな い.そこで本解説では特に規則相に着目しその中で起る 歪の発生, 原因を微視的な観点より説明する. 次いで歪 エネルギーの計算の原理を解説する. 最後に具体的な例 として $\beta$-Brass の相分離(スピノーダル分解)を取り上 げて歪エネルギーの計算を行い結果の解析等について詳 しく説明する.

さて, 格子定数の異なる相(生成相)が整合的に母相か ら生成した場合，母相を基準に考えると生成相を形成す るための(全)歪量は弾性歪と固有歪の和で表わされる. この後者の固有歪とは母相から歪んでない生成相を作る ための歪でそれ自身では応力発生の原因とはならない。 相分離の場合には各々異なる固有歪を持つ(組成の異な る)相が交互に層を成しているが，2つの隣接する層は 互いに弾性的に歪んで整合性を保っている. ての固有歪 の概念は Eshelkyによって確立されたものであるが(2), その後理論は非等方体にまで拡張され現在では歪量や歪 エネルギーを定量的に計算できるまでになっている(3).

一方, 微視的弾性論 (離散型モデル)と言われている分 野では歪や歪エネルギー解析の出発点として, 原子間に

* 新日本製鉄株式会社第 1 技術研究所センター所長 On the Elastic Energy Yielded by Phase Decomposition in Ordered Phase ; Hiroshi Kubo ( $R$ \& D Laboratories-1, Nippon Steel Corporation, Kawasaki) Keywords : phase transformation, beta brass, theoretical estimation, spinodal decomposition, ordering, elestic energy, comfigurational elastic energy 1987 年 4 月 20 日受理

日本金属学会会報第 27 巻第 1 号 (1988)
働く力を考える. 歪や歪エネルギーを計算する際の基本 的な原理は前述の連続体モデルの場合と何ら変らないが, 固有の格子定数は固有の原子(イオン)半径亡読み換えら れる. 同様に Hooke の法則の中に入ってくる弾性定数 が原子間の力の定数で置き換えられる. この様に微視的 弾性論では原子を区別して話を進めるので理論は規則化 に伴う歪の問題や ${ }^{(4)(5)}$ 規則中での析出や相分離の問題に 適している ${ }^{(6)}$. 従って本解説でもての微視的弾性論を用 いるが, 勿論この方法は連続体モデルをも含むのでその 応用範囲は広く一般に相転移に適用され成功を収めてい $ろ^{(7)-(9)}$. 乙の様に本解説で述べる解析手法は必ずしも 相分離(スピノーダル分解)だけに適用されるむのではな いが, 話をすっきりさせるために本文では規則相中の相 分離(スピノーダル分解)についてのみ解説を行っている. 勿論, 相分離をスピノーダル分解だけに限定するのは言 葉の定義から見て正しくない. しかしクラスタリングや 整合析出に伴って発生する歪の問題は, それの応用問題 であるし，また非整合析出もミスファイト転位を考慮に入 れれば，同様に応用問題として把える事ができるのでて こではあえて相分離をスピノーダル分解と解釈して話を 進めて行く.

とてろで微視的弾性論にとって重要な因子は力の定数 を求める事である. そしてての時点で始めて歪の問題は 電子論と結びつけられる. 本稿では第 3 章でこの問題に 触れる.また順序は逆になるが第 2 章では現象論を展開 する. しかしその解説は著者が独自に考えた方法を用い ているので独善的なとてろがあるかもしれない. 特に溶 質 - 格子相互作用係数が dynamical matrix から直接 求められるという結論は(決して間違いではないと思う が)未だ自信がない事を告白しておく．従ってそれを単 なるパラメーターとして扱う従来法の方が安全である事 あ付記しておく. 第 4 章では $\beta$-Brassを例として取り 扱ったがこの外同様に規則相が相分離を起す系としては， $\mathrm{Fe}-\mathrm{Al}^{(10)}, \mathrm{Fe}-\mathrm{Be}^{(11)}, \mathrm{Fe}-\mathrm{Si}^{(12)(13)}, \mathrm{Ni}-\mathrm{Mn}^{(14)}, \mathrm{Cu}-\mathrm{Mn}-$ $\mathrm{Al}^{(15)}$ 等が知られている.

一方, セラミックスであ同様な相分離があって実験と 理論両面からの解析がなされている(16)(17). 実は本会か 
らはセラミックスについても本稿で同時に扱うようにと の要請があったが, 金属の場合とは本質的に異なる点が 多く読者を混乱に招くと考えられるので, 著者の独断で 割愛させていただく事にした。

\section{2. 固溶体の歪エネルギーの導出}

\section{（1）原子がバネで繋がれているモデル}

この節では直観的に理解し易い方法で固溶体中の歪工 ネルギーを算出する。例として $\mathrm{Cu}-\mathrm{Zn}$ の 1 次固溶体を 取り上げる．乙の固溶体の中を誢いてみると図 1 の様に 大きな $\mathrm{Zn}$ 原子(正確にはイオン)之小さな $\mathrm{Cu}$ 原子がお 互いに位置をずらし合いながらひしめきあっており，そ てには “歪が存在する”事が感じられる。 それではての 様な歪を定量的に表現してみよう。まず $\mathrm{Zn}$ および $\mathrm{Cu}$ 原子に外加ら力加えて両者共固溶体の平均原子体積之 同じ大きさになるまで弾性的纪歪ませる．すなわち外か ら仕事 $\Delta W_{1}$ をしてやる. その結果, 固溶体の濃度と同 じ割合でとってきた純 $\mathrm{Zn}$ 原子の塊之純 $\mathrm{Cu}$ 原子の塊は 両者共, 固溶体と同じ格子定数を持つ事になる. この 2 つの塊を貼り合わせた後, 弾性的に歪んだままの両原子 を混合する．ただし各原子はその中心をキチンと平均格 子点上に打くあのとする (強制された平均状態). 各原 子はいったん純金属の中の囲りの原子との結合を切って 新しい混合位置に入れられるので結合エネルギーの差し 引きが生じる。乙の概念によるエネルギー $\Delta W_{2}$ は一般 に化学エネルギー項上呼ばれ，乙れから述べる歪エネル ギーと対比されて記述される場合が多い．2つの和が混 合のエネルギー (エンタルピー)に相当する．次いで $\Delta W_{1}$ で加えていた力を外してやる，すると各原子はほ ぼ元の原子の大きさに戻るが，乙の变化化伴って固溶体 はその内部に歪エネルギーを眝えることになる．内部に 眝えられる歪エネルギーを 2 つのステップを通して定量 化する．第 1 のステップは各原子を格子点上に強制的に (従って外から力 $\Delta W_{3}$ を加えて)おいたまま $\Delta W_{1}$ で加 えていた力をはずしてやる，すると図2 亿示すように各

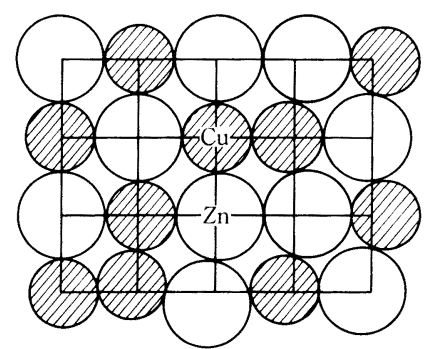

図 1 定性的に描いた $\mathrm{Cu}-\mathrm{Zn} 1$ 次固溶体中の $\mathrm{Zn}$ 原子と $\mathrm{Cu}$ 原子のひしめき合い. 平均格子点 位置から偏位して隣接原子とのコアーの重な りを避けている。

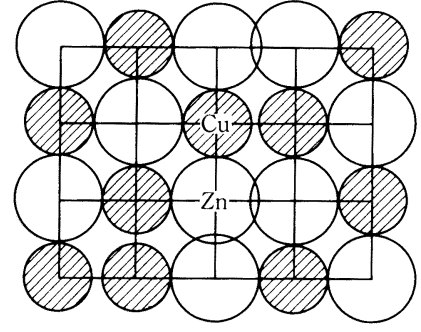

図 2 平均格子点上に強性的に原子を配置した図。 コアーの重なりにより大きな歪が生じている。 原子はオーバーラップしたり隙間をつくったりする．す なわち強く押し合ったり引き合ったりしている．第 2 の ステップは上の $\Delta W_{3}$ でかけていた力を外すことにより， 各原子が格子点からずれることを許す過程, すなわち歪 の緩和過程である．今，原子同士がバネで結ばれている あのと仮定し，そのバネはバネの両端についている原子 の種類によって性質(強さ)が決められるものとする。す ると図 2 の各原子間の状態はそれをバネの伸び縮みに換 算すると平均格子を基準にして次の量だけバネが伸縮し ていることになる(18).

$\hat{u}_{\mathrm{i}}\left(n \gamma-n^{\prime} \gamma^{\prime}\right)=\eta_{\mathrm{ij}}\left[\frac{1}{2} x_{\mathrm{j}}\left(n \gamma-n^{\prime} \gamma^{\prime}\right)\right]\left\{q(n \gamma)+q\left(n^{\prime} \gamma^{\prime}\right)\right]$ $q(n \gamma)=p(n \gamma)-c(\gamma) ;$

$p(n \gamma)$

$=\left\{\begin{array}{l}1: \text { 格子点 } \boldsymbol{x}(n \gamma) \text { 亿溶質原子 } \mathrm{Zn} \text { がある場合 } \\ 0: \text { 格子点 } \boldsymbol{x}(n \gamma) \text { 亿溶媒原子 } \mathrm{Cu} \text { がある場合 }\end{array}\right.$ 乙こに $x_{\mathrm{j}}\left(n \gamma-n^{\prime} \gamma^{\prime}\right)$ は後の便利さを考えて副格子表示 になっており, $n$ 番目の単位胞の $\gamma$ 番目 $(\gamma=1 \sim t)$ の 副格子点之 $n^{\prime}$ 番目の単位胞中 $\gamma^{\prime}$ 番目の副格子点の間の 距離を表わしている. 添字 $\mathrm{j}$ はその $\mathrm{j}$ 方向の距離を示し ている. また $c(\gamma)$ は溶質原子の $\gamma$ 副格子上での平均濃

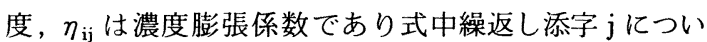
ては和をとる.式(1) 押よび ( 2 )より結局ステップ 1 で は固溶体内部に次の仕事が眝えられる。

$$
\Delta W_{4}=-\frac{1}{2} \sum_{n \gamma \neq n^{\prime} \gamma^{\prime}} S(i k j l) \phi_{i j}\left(n \gamma-n^{\prime} \gamma^{\prime}\right) \hat{u}_{k} \hat{u}_{l}
$$

ここに負の符号は定義により力の定数(バネ定数) $\phi_{\mathrm{ij}}\left(n \gamma-n^{\prime} \gamma^{\prime}\right)$ が変位之は逆の符号を持つ事からきてい る(19)．また $1 / 2$ は対を 2 度数えるので，それに対する 補正である. $S(i k j l)$ は図 2 で示される固溶体が表面を 持っている(繰返しの対象がない)ととに対する補正で次 の様に与えられる。

$$
S(i k j l)=\frac{2 C_{i k j l}}{C_{i k j l}+C_{i l j k}}
$$

ての場合は繰返し添字については特例として和をとらな い. 図 2 の状態はまだ外から力 $\Delta W_{3}$ を加えている状態 であるから，次のステップではこの力を取り去ってやる. すると各原子は互いに力のバランスがとれる位置まで格 子点加変位する(図 1 参照)．变位汇関係している項は 
2 つあって，1つは式(1)で表わされる種類の変位 $\hat{u}$ 之 通常の伸びや縮みを表わす変位 $u$ 之の積で表わされる 項である．屯う少し詳しく説明すると次の様になる。 ま ず $\Delta W_{3}$ の外力を外すと格子は各々 $\mathrm{i}$ 方向に $\phi_{\mathrm{ij}}(n \gamma$ $\left.-\gamma^{\prime}\right) \hat{u}_{\mathrm{j}}\left(n \gamma-\gamma^{\prime}\right)$ の力を持っているので, その方向に変 位 $\left\{u_{\mathrm{i}}(n \gamma)-u_{\mathrm{i}}\left(n^{\prime} \gamma^{\prime}\right)\right]$ を起し歪エネルギーの緩和をす る. 緩和されたエネルギー $\Delta W_{5}$ の量は次の様に表わさ れる。

$$
\begin{aligned}
& \Delta W_{5}=-\frac{1}{4} \sum_{n \gamma \neq n^{\prime} \gamma^{\prime}} 2 \varphi_{\mathrm{i}}\left(n \gamma-n^{\prime} \gamma^{\prime}\right)\left[q(n \gamma)+q\left(n^{\prime} \gamma^{\prime}\right)\right] \\
& {\left[u_{\mathrm{i}}(n \gamma)-u_{\mathrm{i}}\left(n^{\prime} \gamma^{\prime}\right)\right]} \\
& \varphi_{\mathrm{i}}\left(n \gamma-n^{\prime} \gamma^{\prime}\right)=\frac{1}{2} \phi_{\mathrm{ij}}\left(n \gamma-n^{\prime} \gamma^{\prime}\right) \eta_{\mathrm{jk}} x_{\mathrm{k}}\left(n \gamma-n^{\prime} \gamma^{\prime}\right)
\end{aligned}
$$

しかし仮に 1 対の原子が上記の変位をしたとしても格子 は $\mathrm{i}$ 方向に $\phi_{\mathrm{ij}}\left(n \gamma-n^{\prime} \gamma^{\prime}\right)\left[u_{\mathrm{j}}(n \gamma)-u_{\mathrm{j}}\left(n^{\prime} \gamma^{\prime}\right)\right]$ だけの力 を持って変位に抵抗している. この格子の抵抗による仕 事量は

$$
\begin{aligned}
& \Delta W_{6}=-\frac{1}{4} \sum_{n \gamma \neq n_{n^{\prime} \gamma^{\prime}}} \phi_{\mathrm{ij}}\left(n \gamma-n^{\prime} \gamma^{\prime}\right)\left[u_{\mathrm{j}}(n \gamma)-u_{\mathrm{j}}\left(n^{\prime} \gamma^{\prime}\right)\right] \\
& \left\{u_{\mathrm{i}}(n \gamma)-u_{\mathrm{i}}\left(n^{\prime} \gamma^{\prime}\right)\right]
\end{aligned}
$$

と表わされる.系に貯えられた歪エネルギーを正として 全過程の歪エネルギーを加えると

$$
\begin{aligned}
E= & \Delta W_{4}-\Delta W_{5}+\Delta W_{6} \\
& =\frac{1}{2} \sum_{n \gamma} \sum_{n^{\prime} \gamma^{\prime}}\left\{\bar{\varphi}\left(n \gamma-n^{\prime} \gamma^{\prime}\right) q(n \gamma) q\left(n^{\prime} \gamma^{\prime}\right)\right. \\
& +2 \varphi_{\mathrm{i}}\left(n \gamma-n^{\prime} \gamma^{\prime}\right) u_{\mathrm{i}}(n \gamma) q\left(n^{\prime} \gamma^{\prime}\right) \\
& \left.+\phi_{\mathrm{ij}}\left(n \gamma-n^{\prime} \gamma^{\prime}\right) u_{\mathrm{i}}(n \gamma) u_{\mathrm{j}}\left(n^{\prime} \gamma^{\prime}\right)\right\}
\end{aligned}
$$

となる. 式( 5 )および( 7 )から式( 8 )を導くに当たって 係数 $\varphi_{\mathrm{i}}, \phi_{\mathrm{ij}}$ に関する並進および反転対称の性質を用い ている.

\section{（2）歪エネルギーのフーリエ変換表示}

上記 (1)では固溶体は表面を持っている体積 $V$ の系と して考えてきたが，式の表現を簡単にするためにての $V$ の体積のものが積み重なってできた固溶体を考える.す なわち Born-Von Karman の周期的境界条件を導入 する.すると例えば $q(n \gamma)=q(n \gamma+L m)$ となるがこ の様な周期的境界条件を導入しても，エネルギーの表式 ( 8 ) に変化は来たさない。すなわち議論の本質ははずさ ないで斉む.すると式( 8 )の $n$ 亿関する二重和はフー リエ変換するてとによって次の様に波数べクトル $\boldsymbol{k}(q)$ の一重和の形に書き直される。

$$
\begin{aligned}
E= & \frac{N}{2} \sum_{q} \sum_{\gamma} \sum_{\gamma^{\prime}}\left[\Psi\left(\gamma, \gamma^{\prime} \mid q\right) Q(\gamma \mid q) Q^{*}\left(\gamma^{\prime} \mid q\right)\right. \\
& +2 \Psi_{\mathrm{i}}\left(\gamma, \gamma^{\prime} \mid q\right) U_{\mathrm{i}}(\gamma \mid q) Q^{*}\left(\gamma^{\prime} \mid q\right) \\
& \left.+\Phi_{\mathrm{ij}}\left(\gamma, \gamma^{\prime} \mid q\right) U_{\mathrm{i}}(\gamma \mid q) U_{\mathrm{j}}^{*}\left(\gamma^{\prime} \mid q\right)\right]
\end{aligned}
$$

ここに $q$ は $2 \pi / a$ を単位としてとった波数べクトルの 整数の組 $\left(q_{1} q_{2} q_{3}\right)$ を表わしており， $N$ は体積 $V$ 中に
存在する単位胞の数である. ちなみに上式の中の $U_{\mathrm{i}}$ $(\gamma \mid q)$ は実格子上での変位 $u_{\mathrm{i}}(n \gamma)$ をフーリエ展開した 場合に定義される歪波の振幅で次の様に表わされる.

$$
u_{\mathrm{i}}(n \gamma)=\sum_{q} U_{\mathrm{i}}(\gamma \mid q) \exp [i \boldsymbol{k}(q) \cdot \boldsymbol{x}(n \gamma)]
$$

この様にフーリエ展開するということは変位 $u_{\mathrm{i}}(n \gamma)$ が $\sin$ 波や $\cos$ 波の重ね合せによって表現できるという事 であり (数学の定理)その時各波の振幅が $U_{\mathrm{i}}(\gamma \mid q)$ で与 えられるわけである.

式( 8 )の中の $u_{\mathrm{i}}(n \boldsymbol{r})$ は釣合いの位置にいなくてはな らないが式（9)の表示では $E$ を $U_{i}(\gamma \mid q)$ で微分するこ とによって釣合いの位置が求められる.すると歪エネル ギーは濃度だけの関数として次の様に表わされる。

$E=\frac{N}{2} \sum_{q} \sum_{\gamma} \sum_{\gamma^{\prime}}\left[Q(\gamma \mid q) Z\left(\gamma, \gamma^{\prime} \mid q\right) Q^{*}\left(\gamma^{\prime} \mid q\right)\right]$

$Z\left(\gamma, \gamma^{\prime} \mid q\right)=\bar{\Psi}\left(\gamma, \gamma^{\prime} \mid q\right)-\Psi\left(\gamma, \gamma^{\prime} \mid q\right)$

$$
\Phi^{-1}\left(\gamma, \gamma^{\prime} \mid q\right) \Psi^{*}\left(\gamma, \gamma^{\prime} \mid q\right)
$$

ここに $\Phi\left(\gamma, \gamma^{\prime} \mid q\right)$ は dynamical matrix であり, 力の 定数 $\Phi_{\mathrm{ij}}\left(n \gamma-n \gamma^{\prime}\right)$ からフーリエ変換を経て求められる $3 t \times 3 t$ の実対称行列である. また他の係数も $\phi_{\mathrm{ij}}(n \gamma$ $\left.-n \gamma^{\prime}\right)$ から (3)( 4 )および ( 5 )によって求められる. のうち $\bar{\Psi}\left(\gamma, \gamma^{\prime} \mid q\right)$ はスカラ一の実数で与えられるが, $\Psi\left(\gamma, \gamma^{\prime} \mid q\right)$ は $t \times 3 t$ の行列で与えられ各要素は純虚数之 なる. 式(11)の特徴は各濃度波について濃度之係数が分 離されて(積の形)書かれている事である. したがって, $Q(\gamma \mid q) Q^{*}\left(\gamma^{\prime} \mid q\right) \geq 0$ であるてとを考えると，ある波数 $q$ を持った濃度波が起るか否かは $Z\left(\gamma, \gamma^{\prime} \mid q\right)$ 符号によっ て決まる事が分かる。

\section{3. 電子論に基づく歪エネルギーの表示}

\section{（1）純金属のイオン対間相互作用エネルギー}

歪エネルギーは前節で説明した様に, 結局イオン間に 働くポテンシャルの相互作用を求めることに㷌着する. このためには電子系のエネルギーとイオン系のエネルギー の和を求めておいて, その中からイオン対間のポテンシャ ルに渉る項を抜き出せばよい，前者は金属の凝集エネル ギーを求めるのと同等である，すると結局イオン対間の 相互作用 (の結晶に渡る和) $V$ は次の 3 つの項から成り 立つことが分かる。

$$
V=V_{\text {id }}+V_{\mathrm{C}}+V_{\mathrm{R}}
$$

ここに $V_{\mathrm{id}}$ は伝導電子を介してのイオン間ポテンシャ ル (ion-electron-ion potential), $V_{\mathrm{C}}$ はイオン間の クーロン反発エネルギー, $V_{\mathrm{R}}$ はイオンコアーの重なり による反発項である。

まず, 負電荷を持つ一様な自由電子ガスの中に, 規則 性を持って置かれた $Z e$ の正電荷(イオン)を考える.す ると図 3 に示す様に着目するイオン A の囲りにはク一 ロン相互作用によって電子が集まって来る，とてろがて 


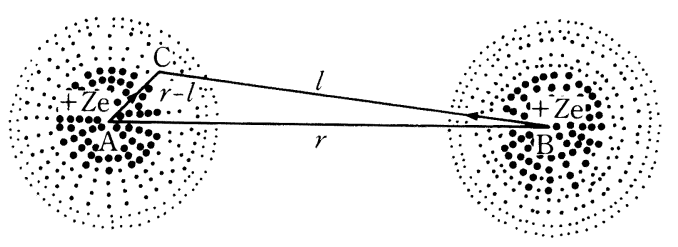

図 3 イオンの囲りの遮蔽電子とion-electronion 相互作用 (矢印).

の遮蔽電子雲 $\mathrm{C}$ は $\mathrm{A}$ と同様に遮蔽された $\mathrm{B}$ 原子から クーロン引力を受ける．見方を変えてイオンにのみ着目 すると，Aと B は恰かも直接相互作用を及ばし合って 矢印の方向に動こうとしているかの如く見える。乙れを 戸谷は ion-electron-ion 相互作用と名付けた ${ }^{(20)}$ 。乙 の問題はイオンの囲りに集まっている電子雲の密度を 求めるてとから始めなくてはならない。乙の集り具合 $\delta \rho(\boldsymbol{r})$ は Hatree 近似の範聿で(電子のスピンによる区別 を考えず 1 つの電子に着目し，他の電子は存在確率に比例 した電荷雲とみなす方法), self-consistent 亿求める 事ができる. 求めた密度分布 $\delta \rho(\boldsymbol{r})$ を電磁気学でよく 知られているポアソンの式に入れると, 電子が感ずるポ テンシャル $w(\boldsymbol{r})$ は遮蔽されたポテンシャルとしてよく 教科書にあるように振動する形で求められる. 電子雲 C はての遮蔽されたポテンシャルを感じているわけである が $w(\boldsymbol{r})$ の中には遮蔽電子からの寄与が含まれているの でその分を差し引いて相互作用を求める必要がある。す るとイオン A と B の間の ion-electron-ion 相互作用 は逆格子空間表示で,

$$
\begin{aligned}
v_{\text {id }}(q)= & \frac{|\boldsymbol{k}(q)|^{2}}{4 \pi e^{2}}\left[w^{0}(q)\right]^{2}\left[\frac{1}{\varepsilon(q)}-1\right] \\
\varepsilon(q)= & 1+\frac{2 m e\left|\boldsymbol{k}_{\mathrm{f}}(q)\right|}{\pi h^{2}|\boldsymbol{k}(q)|^{2}}\left[1+\frac{4\left|\boldsymbol{k}_{\mathrm{f}}(q)\right|^{2}-|\boldsymbol{k}(q)|^{2}}{4\left|\boldsymbol{k}_{\mathrm{f}}(q) \cdot \boldsymbol{k}(q)\right|}\right. \\
& \left.\times \log \left|\frac{2 \boldsymbol{k}_{\mathrm{f}}(q)-\boldsymbol{k}(q)}{2 \boldsymbol{k}_{\mathrm{f}}(q)+\boldsymbol{k}(q)}\right|\right]
\end{aligned}
$$

となる。乙こに $w^{\circ}(q)$ は裸のイオンポテンシャル $w^{\circ}\left(r_{\mathrm{A}}-r_{\mathrm{B}}\right)$ をフーリエ変換したものであり, $\varepsilon(q)$ は電媒 定数, $\boldsymbol{k}_{\mathrm{f}}$ はフェルミ面上の波数ベクトルである. 裸の イオンポテンシャル $w^{\circ}\left(r_{\mathrm{A}}-r_{\mathrm{B}}\right)$ はイオンー電子間に働 くクーロン相互作用(引力) とイオン殼内の軌道電子から 受ける哌力項とから成る. 伝導電子がイオン殸に近づき 殸内入入っていくと原子殼からは引力を受けるが, 殼内 の電子からはパウリの排他律に起因する強い斥力を受け る.乙の項をきちんと計算すると面倒な形となるし，ま た定量的でもないので Harrison はこの項をパラメー ターを含むボルン・メーヤー型のポテンシャルで置き換 えた ${ }^{(21)}$. こうして関数 $w^{\circ}\left(r_{\mathrm{A}}-r_{\mathrm{B}}\right)$ は実空間で簡単な形 で表わす事ができるので，それを使って $w^{\circ}(q)$ を $q$ の 関数として求める事ができる.

$$
\begin{aligned}
-Z w^{\circ}(q) & =v_{\mathrm{C}}(q)-v_{\mathrm{R}}(q) \\
& =\frac{4 \pi n Z^{2} e^{2}}{|\boldsymbol{k}(q)|^{2}}-\frac{n Z^{2} A}{\left[1+|\boldsymbol{k}(q) \cdot \boldsymbol{\rho}|^{2}\right]^{2}}
\end{aligned}
$$

ここに $v_{\mathrm{C}}(q)$ および $v_{\mathrm{R}}(q)$ は各々イオン間のクーロン 相互作用之斥力項である. 係数の $-Z$ はイオンーイオ ン間の相互作用がイオン - 電子間のそれの- $Z$ 倍であ ることから来ている. また $n$ は $1 \mathrm{~cm}^{3}(1 \mathrm{cc})$ 中のイオン の数である. $A$ 之 $\rho$ はパラメーターであり例えば $\mathrm{Al}$ に 対しては $Z^{2} A=90.2 \times 10^{-19} \mathrm{~J} \cdot \mathrm{nm}, \rho=0.02 \mathrm{~nm}$ とな る. ion-electron-ion 相互作用 $V_{\text {id }}$ は $v_{\text {id }}(q)$ (エネル ギー波数特性と呼ばれ通常 $F(q)$ と表わす)から逆フー リエ変換して $w_{\text {id }}\left(r_{\mathrm{A}}-r_{\mathrm{B}}\right)$ を求め, 更にそれの $r_{\mathrm{A}}$ 扰よ び $r_{\mathrm{B}}$ について和をとる事によって得られる. 結果は

$V_{\text {id }}=\sum_{r_{\mathrm{A}}} \sum_{r_{\mathrm{B}}} w_{\text {id }}\left(r_{\mathrm{A}}-r_{\mathrm{B}}\right)=\frac{V}{2} \sum_{q}^{\prime} S(g) S^{*}(g) v_{\text {id }}(g)$

こてに $S(g)$ は構造因子であり $g$ は結晶の逆格子ベクト ルを表わしている. 上式は電子論の分野でバンド構造エ ネルギーと呼ばれる項であり結晶構造に依存した值を持 つ. 式(14)は更に厳密に表わそうとすると, 電子のスピ ンに起因する交換相互作用や配置に関する相関効果を考 えた式を導入しなくてはならないがそれらはこてでは本 質でもないし，それらが $\varepsilon(q)$ に与える影響む大きくな いのでここではこれ以上論ずることはしない。

式(13)における他の 2 つの項 $V_{\mathrm{C}}$ と $V_{\mathrm{R}}$ あ式(16)で与 えられた $v_{\mathrm{C}}(q)$ および $v_{\mathrm{R}}(q)$ を逆フーリ工変換し， $v_{\mathrm{C}}$ $\left(r_{\mathrm{A}}-r_{\mathrm{B}}\right)$ および $v_{\mathrm{R}}\left(r_{\mathrm{A}}-r_{\mathrm{B}}\right)$ を求め次いで $r_{\mathrm{A}}$ および $r_{\mathrm{B}}$ について格子和をとれば式(17) と同じ式が導かれる。和 をとる前の $w_{\mathrm{id}}(r)+v_{\mathrm{C}}(r)+v_{\mathrm{R}}(r)$ は有効対間ポテンシャ ルと呼ばれるがその形は図 4 亿示す様に振動しそのすそ が遠くの方まで引いているのが特徴である.乙れはフェ ルミ粒子である電子の波数ベクトルを $\boldsymbol{k}(q)=0 \sim \boldsymbol{k}_{\mathrm{f}}(q)$ としたためである. 相互作用の振動が現実に存在するて とは疑問の余地はなく合金であ散漫散乱の実験によって 確認されている(22).

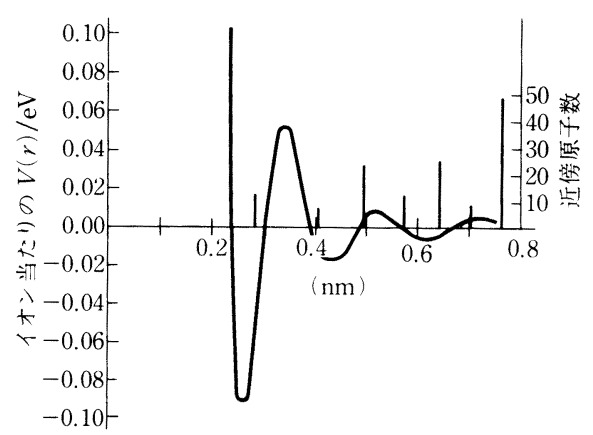

図 $4 \mathrm{Al}$ の有効対間相互作用エネルギー。縦軸に 平行な線の高さは近傍原子の数を表わしてい る. 


\section{（2）多元系における歪エネルギー}

この節では多元系金属合金を扱う．と言っても Coherent Potential 近似による計算をするつもりはない。む しろ定性的ではあるが話の筋が分かり易いPseudoPotential の結果を引き続き利用していく. 式(14), (16) より式(13)の全対間相互作用エネルギー $V$ は式(2)で 定義した $p_{\sigma}(n \gamma)$ を用いると次の様に表わされる. $\begin{aligned} V= & \frac{1}{2 N} \sum_{q}^{\prime} \sum_{\sigma} \sum_{\sigma^{\prime}} W_{\sigma \sigma^{\prime}}(q) \sum_{n \gamma} \sum_{n^{\prime} \gamma^{\prime}} p_{\sigma}(n \boldsymbol{\gamma}) p_{\sigma^{\prime}}\left(n^{\prime} \boldsymbol{\gamma}^{\prime}\right) \\ & \times \exp \left[-i \boldsymbol{k}(q) \cdot\left\{\boldsymbol{x}\left(n \boldsymbol{\gamma}-n^{\prime} \boldsymbol{\gamma}^{\prime}\right)+\boldsymbol{u}\left(n \boldsymbol{\gamma}-n^{\prime} \boldsymbol{\gamma}^{\prime}\right)\right\}\right]\end{aligned}$

$W_{\sigma \sigma^{\prime}}(q)=v_{\text {id }}(q)\left\{\left|w^{\circ}(q)\right|^{2} \rightarrow w_{\sigma}^{\circ}(q) w_{\sigma^{\prime}}^{\circ}(q)\right\}$

$$
+v_{\mathrm{C}}(q)\left\{Z^{2} \rightarrow Z_{\sigma} Z_{\sigma^{\prime}}\right\}+v_{\mathrm{R}}(q)\left\{Z^{2} \rightarrow Z_{\sigma} Z_{\sigma^{\prime}}\right\}
$$

ここに $\sigma, \sigma^{\prime}$ は原子の種類を表わしている.上式で変 位 $\boldsymbol{u}(n \gamma)$ が小さいとして展開し 2 次の項までとる.

$p_{\sigma}(n \gamma) p_{\sigma^{\prime}}\left(n^{\prime} \gamma^{\prime}\right)$ の積を式( 2$)$ の $q_{\sigma}(n \gamma)$ と $c_{\sigma}(\gamma)$ を用 いて書き換えると, 前章の式( 9$)$ 加式(12) に渡って行っ たのと同じ手続きを得てフーリエ変換した形で対間エネ ルギー $V$ を求める事ができる.

$V=\frac{N}{2} \sum_{q} \sum_{\sigma} \sum_{\sigma^{\prime}} \sum_{\gamma} \sum_{\gamma^{\prime}}\left[Q_{\sigma}(\gamma \mid q) Y_{\sigma \sigma^{\prime}}\left(\gamma, \gamma^{\prime} \mid q\right) Q_{\sigma^{\prime}}^{*}(\gamma \mid q)\right]$

$$
\begin{aligned}
Y_{\sigma \sigma^{\prime}}\left(\gamma, \gamma^{\prime} \mid q\right)= & \Omega_{\sigma \sigma^{\prime}}\left(\gamma, \gamma^{\prime} \mid q\right)+\bar{\Psi}_{\sigma \sigma^{\prime}}\left(\gamma, \gamma^{\prime} \mid q\right) \\
& -\Psi_{\mathrm{i} \sigma}\left(\gamma, \gamma^{\prime} \mid q\right) \Phi_{\mathrm{ij}}^{-1}\left(\gamma, \gamma^{\prime} \mid q\right) \Psi_{\mathrm{j} \sigma^{\prime}}^{*}\left(\gamma, \gamma^{\prime} \mid q\right)
\end{aligned}
$$

$$
L_{\sigma \sigma^{\prime}}\left(\gamma, \gamma^{\prime} \mid q\right)=\Omega_{\sigma \sigma^{\prime}}\left(\gamma, \gamma^{\prime} \mid q\right)+\bar{\Psi}_{\sigma \sigma^{\prime}}\left(\gamma, \gamma^{\prime} \mid q\right)
$$$$
\Psi_{\mathrm{i} \sigma}\left(\gamma, \gamma^{\prime} \mid q\right)
$$

$$
=\sum_{\boldsymbol{g}} W_{\sigma \sigma^{\prime}}(|g+q|) S\left(\gamma, \gamma^{\prime} \mid q\right)
$$

$=i \sum_{\sigma} c_{\sigma^{\prime}}(\gamma) \sum_{g} k_{\mathrm{i}}(g+q) W_{\sigma \sigma^{\prime}}(|g+q|) S\left(\gamma, \gamma^{\prime} \mid q\right)$ (23)

$$
\Phi_{\mathrm{i} \sigma}\left(\gamma, \gamma^{\prime} \mid q\right)=\sum_{\sigma}^{g} \sum_{\sigma^{\prime}} c_{\sigma}(\gamma) c_{\sigma^{\prime}}\left(\gamma^{\prime}\right) \sum_{g} k_{\mathrm{i}}(g+q) k_{\mathrm{j}}(g+q)
$$$$
\times W_{\sigma \sigma^{\prime}}(|g+q|) S\left(\gamma, \gamma^{\prime} \mid q\right)
$$

$S\left(\boldsymbol{\gamma}, \gamma^{\prime} \mid q\right)=\exp \left[-i \boldsymbol{k}(q) \cdot \boldsymbol{x}\left(\boldsymbol{\gamma}-\boldsymbol{\gamma}^{\prime}\right)\right]$

式(21)の第 1 項之第 2 項の和は各原子が格子点上にきち んとその中心を置いている場合の全エネルギーを表わし ており, 前章で述べた化学エネルギー項 $\Delta W_{2}$ と格子上 で原子がひしめき合っている歪エネルギー $\Delta W_{4}$ との和 である. 従って式の中で形式的に化学エネルギー項 $\Omega$ と歪エネルギー項 $\bar{\Psi} に$ 分けたが，それらを電子論に基 ゔいて分けることはできず式(22)に与えられる様にそれ らの和が $W$ か求められるに過ぎない. しかし現象論 的解析によれば $\bar{\Psi}$ は dynamical matrix から計算に よって求め得る量である.

$\mathrm{A}-\mathrm{B} 2$ 元素の場合は $q_{\mathrm{A}}(n \gamma)+q_{\mathrm{B}}(n \gamma)=0$ を考慮し て溶質原子 B のみの関数として $q(n \gamma)=q_{\mathrm{B}}(n \gamma)$ とお けば式(12)の $Z\left(\gamma, \gamma^{\prime} \mid q\right)$ を用いて $V$ は次の様に表わさ れる。

$$
\begin{aligned}
V= & E_{\text {chem }}+E_{\text {elast }}=\frac{N}{2} \sum_{q} \sum_{\gamma} \sum_{\gamma^{\prime}}\left[Q ( \gamma | q ) \left\{\Omega\left(\gamma, \gamma^{\prime} \mid q\right)\right.\right. \\
& \left.\left.+Z\left(\gamma, \gamma^{\prime} \mid q\right)\right\} Q^{*}\left(\gamma^{\prime} \mid q\right)\right]
\end{aligned}
$$

$\Omega\left(\gamma, \gamma^{\prime} \mid q\right)$

$$
=\Omega_{\mathrm{AA}}\left(\gamma, \gamma^{\prime} \mid q\right)+\Omega_{\mathrm{BB}}\left(\gamma, \gamma^{\prime} \mid q\right)-2 \Omega_{\mathrm{AB}}\left(\gamma, \gamma^{\prime} \mid q\right) \quad(27)
$$

ここに化学エネルギー $\Omega$ は逆格子空間における規則化 エネルギーである. $Z\left(\gamma, \gamma^{\prime} \mid q\right)$ の中の $\bar{\Psi}$ および $\Psi_{\mathrm{i}}$ は

$\bar{\Psi}\left(\gamma, \gamma^{\prime} \mid q\right)$

$=\Psi_{\mathrm{AA}}\left(\gamma, \gamma^{\prime} \mid q\right)+\Psi_{\mathrm{BB}}\left(\gamma, \gamma^{\prime} \mid q\right)-2 \Psi_{\mathrm{AB}}\left(\gamma, \gamma^{\prime} \mid q\right)(28)$

$\Psi_{\mathrm{i}}\left(\gamma, \gamma^{\prime} \mid q\right)=\Psi_{\mathrm{iA}}\left(\gamma, \gamma^{\prime} \mid q\right)-\Psi_{\mathrm{iB}}\left(\gamma, \gamma^{\prime} \mid \mathrm{q}\right)$

となる.式(26)の $E_{\text {elast }}$ は現象論的に導いた歪エネル ギーの式(11)と一致する.

\section{4. $\quad \beta$-Brass における相分離と歪エネルギー}

\section{（1）規則化エネルギーと副格子上での相分離}

ここでは最も簡単な規則相である B2 型構造を有する $\beta$-Brassを取り上げる.一般に規則相は低温で相分離 あしくは再規則化するが， $\beta$-Brass あ低温で相分離を 起してより安定な相へと変化する. すなわち $T=0 \mathrm{~K}$ ではエントロピー $S=0$ でなくてはならないから, 化 学量論組成 $(50: 50)$ 以外の組成を持つ B2 型規則相は低 温ではそのままの状態では存在しえず相分離したり, あ るいは再規則化したりしてェントロピー0の状態に近づ いていくわけである. その際, 相分離が優先するのかあ るいは再規則化が優先するのかは規則化エネルギーの符 号の正負によって決められる.

Inden は種々の熱力学データから $\beta$ - Brass の規則化 エネルギーを次の様に求めている(23).

$$
\omega^{(1)}=-320 k_{\mathrm{B}}, \quad \omega^{(2)}=-180 k_{\mathrm{B}}
$$

ここに $\omega^{(n)}$ は $n$ 番目の隣接原子との間の規則化エネル ギーで結合エネルギー $\nu_{\mathrm{AB}}^{(n)}$ を用いると $\omega^{(n)}=\nu_{\mathrm{CuZn}}^{(n)}$ $-\left(\nu_{\mathrm{CuCu}}^{(n)}+\nu_{\mathrm{ZnZn}}^{(n)}\right) / 2$ と表わされる. 従って上記の規則 化エネルギーの負の値は, 温度の降下とともに不規則 $\mathrm{BCC} \rightarrow \mathrm{B} 2$ 型 $\rightarrow \mathrm{DO}_{3}$ 型規則相へと相変化が進むととを 意味している( ${ }^{(5)}$. とてろが電顕を用いた実験によると $\beta$ Brass は恰む $\omega^{(2)}>0$ であるかの如く振舞って低温で はB2 型規則相を持ったまま相分離(スピノーダル分解) を起すことが知られている(24)(25). 乙の矛盾は明らかに 歪エネルギーを考慮に入れていない事に起因しているも のと思われる．以下，順を追って説明する.

簡単のためにまず歪エネルギーを零と仮定する． $\beta$ Brass は $\mathrm{Cu}-$ rich $\alpha$ 副格子と $\mathrm{Zn}-\mathrm{rich} な \beta$ 副格子 とに分けて考えるのが便利である. 図 5 はそれらの副格

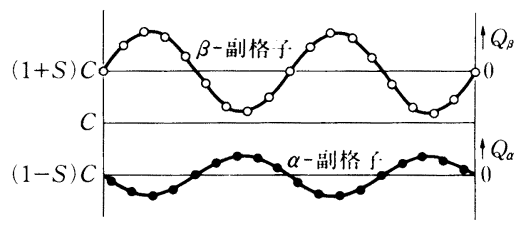

図 $5 \beta$-Brass の副格子上での分解波. 位相が $\pi$ だけづれている optical モードの波. 
子上の相分離を理解するために描いた概念図であり縦軸 が $\mathrm{Zn}$ 原子の濃度, 横軸が [100]方向の原子面の位置を 表わしている. 各副格子上の正弦波は分解の様子を表わ しており，一般に分解濃度波と呼ばれている．濃度波の 上の丸印が格子面位置およびその面内での $\mathrm{Zn}$ 濃度を示 している. 特定な波長 $\lambda(=1 / q)$ を持った濃度波が $\alpha$ 副格子と $\beta$ 副格子上で図の様に生成してきた場合，そ れらによるエネルギーの変化分 $F_{\mathrm{p}}(q)$ は式 $(26)$ にり 次の様に表わされる.

$$
\begin{aligned}
F_{\mathrm{p}}(q)=\frac{N}{2} \sum_{\gamma} \sum_{\gamma^{\prime}} Q(\gamma \mid q)\left[\Delta Y\left(\gamma, \gamma^{\prime} \mid q\right)\right] Q^{*}(\gamma \mid q) \\
\Delta Y\left(\gamma, \gamma^{\prime} \mid q\right)=\left[Z\left(\gamma, \gamma^{\prime} \mid q\right)-<Z\left(\gamma, \gamma^{\prime} \mid q\right)>\right] \\
+\left[\Omega\left(\gamma, \gamma^{\prime} \mid q\right)-<\Omega\left(\gamma, \gamma^{\prime} \mid q\right)>\right]
\end{aligned}
$$

ここに<>は第 1 B.Z.内での平均値を表わしているが, これは配列によるエネルギーの零点を母相に置くための 操作である．配列のエネルギー $V_{\text {conf }}$ は $F_{\mathrm{p}}(q)$ を第 1 B.Z. に渡って和をとる事によって求められる事に注意 しょう. $F_{\mathrm{p}}(q)$ の具体的な形を見るために振幅 $Q(\alpha \mid q)$ と $Q(\beta \mid q)$ を直交軸とする座標系に $F_{\mathrm{p}}(q)$ を描く.す ると図 6 に示す様な 2 次曲面が得られる. この曲面の形 は今の場合, $\Omega(\alpha, \alpha \mid q), \Omega(\beta, \beta \mid q)$ および $\Omega(\alpha, \beta \mid q)$ の示す値によって変化するが, 図6では二葉双曲線となっ ている．乙の場合直線 $W_{1}$ と $W_{2}$ で分けられた凸曲面の 領域に成長した濃度波は全体のエネルギ一を減少させる ので，その振幅をますます増大して成長する。乙れに対 して凹曲面領域に生長した濃度波は全体のエネルギーを 高めるのですぐ消滅してしまう. 分解はエネルギーの下 り具合が最も大きな方向に起るので, 曲面上で最む小さ な曲率の值 $\Delta \Omega(-)$ と(凸面であれば $\Delta \Omega(-)<0)$ その 方向 $Q(-)$ を知る事は重要である。乙れは副格子 $\gamma$ と $\gamma^{\prime}$ にかかわる $(2 \times 2)$ 行列 $\Delta \Omega\left(\gamma, \gamma^{\prime} \mid q\right)=\Omega\left(\gamma, \gamma^{\prime} \mid q\right)$ $-<\Omega\left(\gamma, \gamma^{\prime} \mid q\right)>$ の固有值および固有べクトルを求め る事に相当する.

さて, 先に述べた様に化学エネルギー項のみを考えた 場合には， $\beta$-Brass 相 (B2 型規則相)は低温で $\mathrm{DO}_{3}$ 型

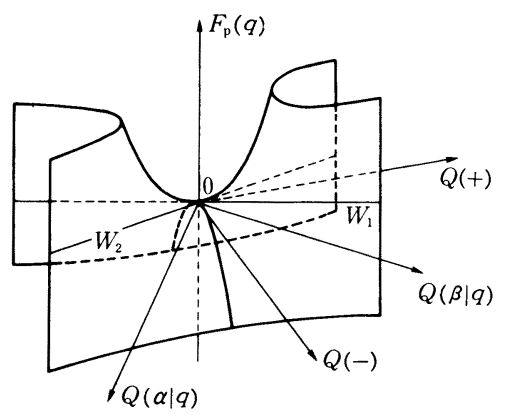

図 6 定性的に描いた波数べクトル $\boldsymbol{k}(\boldsymbol{q})$ の分解波 に対する歪エネルギー曲面. $Q(-)$ 打よび $Q(+)$ は各々最小および最大曲率の方向.
規則相に変化する筈であるが，自由エネルギーを計算す る事によりより正確にこの事を示そう. 自由エネルギー と言うからには $\omega^{(n)}$ だけではなくてエントロピー項も 考えなくてはいけない.ここでは簡単のために BraggWilliams 近似を用い各副格子上での原子の配列のエン トロピーだけを考慮に入れて話を進める。このエントロ ピー項からの寄与を各副格子上で各々 $\Omega(\alpha, \alpha \mid 0)$ および $\Omega(\beta, \beta \mid 0)$ として $\Omega(\alpha, \alpha \mid q), \Omega(\beta, \beta \mid q)$ にそれぞれ加 えておく. エントロピー項を含んだ $\Omega\left(\gamma, \gamma^{\prime} \mid q\right)$ より求 められた $\Delta \Omega(-)$ は第 1 B.Z.内の頂点位置 $(000)$ と $(1 / 2$ 1/2 1/2)を中心として負の領域を生ずる ${ }^{(6)}$. すなわちそ れらの負の領域では分解波が生長しうる.その中の (110) 面を取り出して描いたのが図 7 で図中, 点を付した領域 が負の領域である. また空間内の任意の点は波数べクト ルを表わしており，その大きさは図 5 の副格子上での濃 度波の波長の逆数である. 乙の時, 固有べクトル $Q(-)$ の方向が $\alpha$ 副格子と $\beta$ 副格子上での濃度波の振幅の比 之横軸方向への相対的なずれを決める。計算によれば図 5 に示す様に $\pi$ だけその位相がずれている．ての様な 波の Pair は格子振動の分野で optical モードの波と呼 ばれている。一方位相が揃った波の Pair は acoustic モードの波と呼ばれている. 後者は $\Delta \Omega\left(\gamma, \gamma^{\prime} \mid q\right)$ 行列 のもう 1 つの固有值 $\Delta \Omega(+)$ に対応するものであるが， この $\Delta \Omega(+)$ は曲面の最大曲率を表わしている．乙の様 にある特定な波長を持つ濃度波は optical なモードと acoustic なモードと 2 種類ある. ところで optical モー ドの波では図 5 に示すようにそれらの半波長分の領域で は B2 型規則相の規則度を高め隣接する半波長分の領域 では逆に規則度を下げる結果となる。図1より明らかな 様に B2 型規則相の中でその規則度が上ると大小の原子 が順に並ぶので歪は小さくなる。しかし逆に規則度が下 がれば歪は大きくなる，従って図 5 に示すような optical モードの相分離ではそれらの両者の差し引きによって決

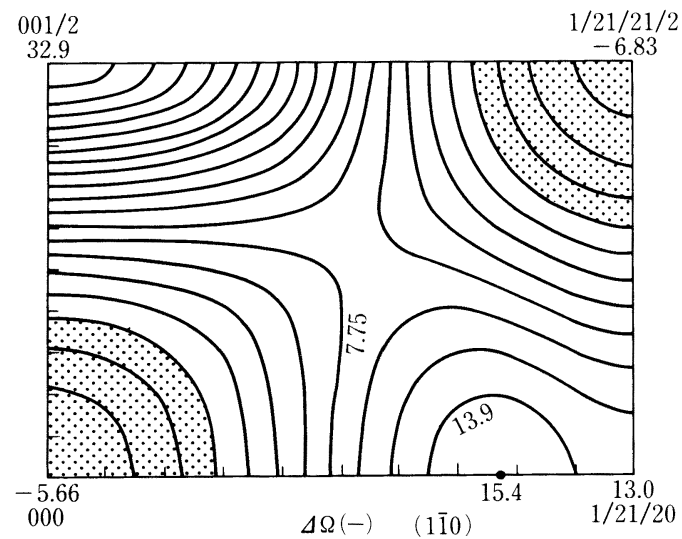

図 7 化学エネルギーのみを計算した配列の自由エ ネルギー等高線. 単位は $10^{-21} \mathrm{~J} /$ atom. 
まる歪エネルギーの寄与が大きくなって分解が起こり得 ない可能性もある. しかし図 7 は歪エネルギーを考慮に 入れない場合には, optical モードのスピノーダル分解 が起こり得ることを示している。一方，逆格子点 $(1 / 2$ 1/21/2)近傍にも $\Delta \Omega(-)$ の負の領域がある. $\mathrm{B} 2$ 型規 則相の中に $\boldsymbol{k}(q)=(1 / 21 / 21 / 2)$ の濃度波が起るとよ く知られている様に, $\mathrm{B} 2$ 型は $\mathrm{DO}_{3}$ 型規則相へと変化す る.乙れはIndenが期待した結果と一致する. 事実, 彼が計算によって求めた状態図には，乙の $\mathrm{DO}_{3}$ 型規則相 が安定相として描かれている(23). 上記の如く化学エネル ギー項のみを考えると相分離 (スピノーダル分解) と共に $\mathrm{DO}_{3}$ 型規則相への変化も可能であるという結論に達す るが, これに歪エネルギーを加えると, 状況は変ってく る. 式(31)(32)を用いて配列の歪エネルギーを考慮し， その化学エネルギーと合わせて全エネルギーの固有值 $\Delta Y($ 一) を求めると図 8 のように(1/2 1/2 1/2)近傍の負 の領域はなくなって $(000)$ 付近の負の領域のみが残る. 乙れは $\mathrm{DO}_{3}$ 型規則相の様な原子の配列は隣りに同種の 原子がくるので大きな歪が生ずるからである．乙の様に 原子配列の歪を考慮に入れると $\mathrm{B} 2$ 型規則相を持つ $\beta$ Brass が $\mathrm{DO}_{3}$ 型規則相を伴わないで相分離する事を矛 盾なく説明できる.ちなみに図 8 の $(000)$ 近傍の負の領 域では $<001>$ 方向に谷を持ち $\boldsymbol{k}(q)=(0.06,0,0)$ で極 小値を示す。

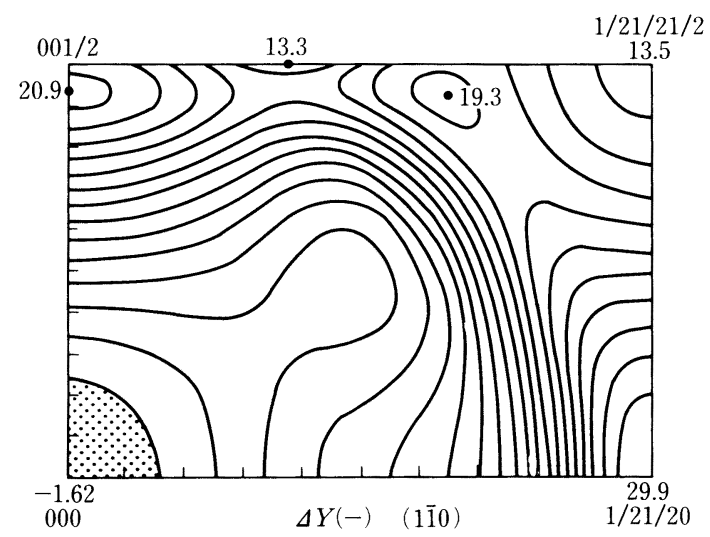

図 8 化学エネルギーと歪エネルギーの両者を考慮 して計算した配列の自由エネルギー(係数)等 高線. 単位は $10^{-21} \mathrm{~J} /$ atom.

\section{（2）配列の歪エネルギーと $\mathbf{X}$ 線の散漫散乱}

配列の歪エネルギーを求めることは, 結局式(12)の $Z\left(\gamma, \gamma^{\prime} \mid q\right)$ を第 1 B.Z.内で求める事に帰着する. 従って この中に現われてくる $\bar{\Psi}, \Psi, \Phi^{-1}$ を求める必要がある. これらはいずれも dynamical matrix が分かりさえすれ ば式( 3 )や式( 6 )より求められるので問題は dynamical matrix を求める事と同等である. よく知られている様 に熱中性子の非弾性散漫散乱強度の解析から力の定数を
求めて dynamical matrix を構成するのがこの分野で の正攻法である. 事実, $\beta$-Brassについてはての方法 によって力の定数が求められている(26). 従ってその值 を使えばよいわけであるが，小さい単結晶しか得られな い場合には X 線による散漫散乱を利用する事ができる。 $\beta$-Brass の場合にはこの X 線による散漫散乱強度はか なり強く, 図 9 の様に<110>方向に長く尾を引いてい

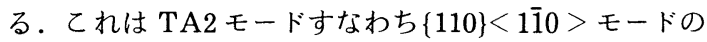

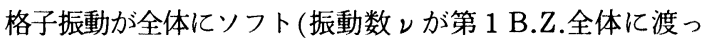
て小さい)である事が原因である.さてての散漫散乱を 上手に解析すると力の定数 $\Phi_{\mathrm{ij}}$ 之溶質原子 - 格子相互作 用係数 $\varphi_{\mathrm{i}}$ とを同時に直接求める事ができる (a)および (b)にはてのようにして求めた $(2 \times 2)$ 行列, $\Delta Z\left(\gamma, \gamma^{\prime} \mid q\right)$ からその固有值として得られた $\Delta Z(+)$ と $\Delta Z(-)$ の值が示してある. 図はよ゙ちらあ第 1 B.Z.内の $(1 \overline{1} 0)$ 面を示しており, その中に $\Delta Z(+)$ および $\Delta Z(-)$ の等高線が描かれている. 明らかに極小の谷は $\Delta Z(+)$ でも $\Delta Z(-)$ でも原点から<001>方向に伸びているがて の事は分解が< $<01>$ 方向に起ると歪エネルギー的に有利 である事を示している．興味のある事は optical モードの 長波長分解は $\Delta Z(+)>0$ であって分解を阻止する働き をする事である. これは前にも述べた様に規則度の変化 に対応して隣り合う原子の種類が変るためであるが，乙 の結果は図 7 の $\Omega(-)$ の結果と対峙するものである.し かし結果としては図 8 亿示すように化学エネルギー項が 歪を上まわって optical モードの分解を起す事になって いる.

図 11 は $\beta$-Brass の分解の様子を示す透過電顕写真 であり図 12 はそれの説明図である.スピノーダル分解 した相では隣り合う $\mathrm{P}$ 層と $\mathrm{Q}$ 層で濃度が異なるから， それに伴って格子定数が変化する. 今各層内での単位胞 を誇張して点線の如く描くとそれら 2 つ単位胞は格子 の整合性を保つために弾性的に歪んで実線の如くなって いる筈である．巨視的なスケールで言えばこのポアソン

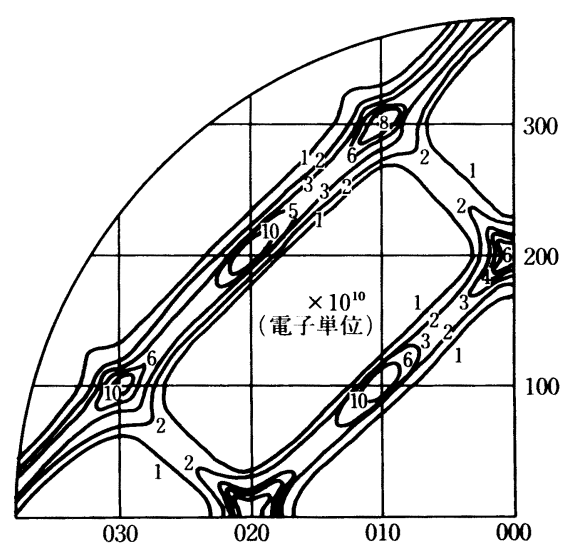

図 $9 \beta$-Brassよりの X 線散漫散乱強度. 
(a)

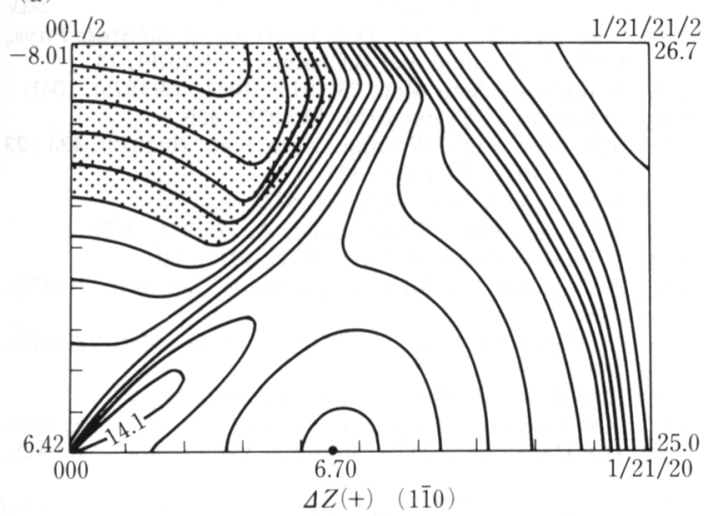

(b)

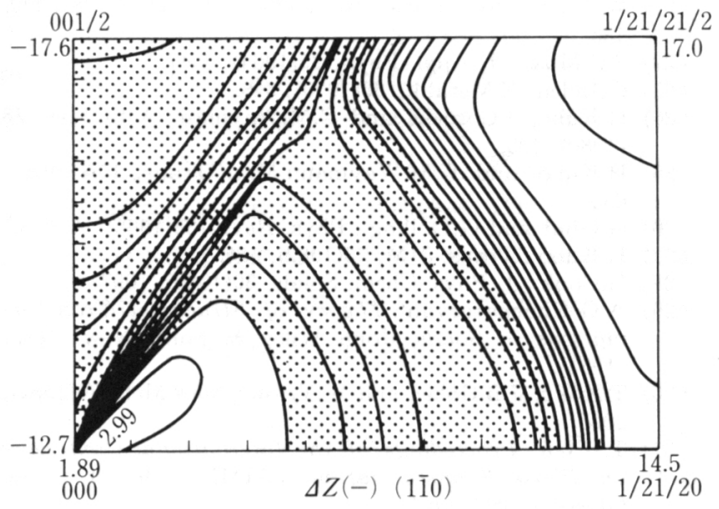

図 10 配列の歪エネルギー(係数)等高線. $\Delta Z(+)$ および $\Delta Z(-)$ は各々図 6 の最大および最小 曲率を表わす。単位, $10^{-21} \mathrm{~J} /$ atom.

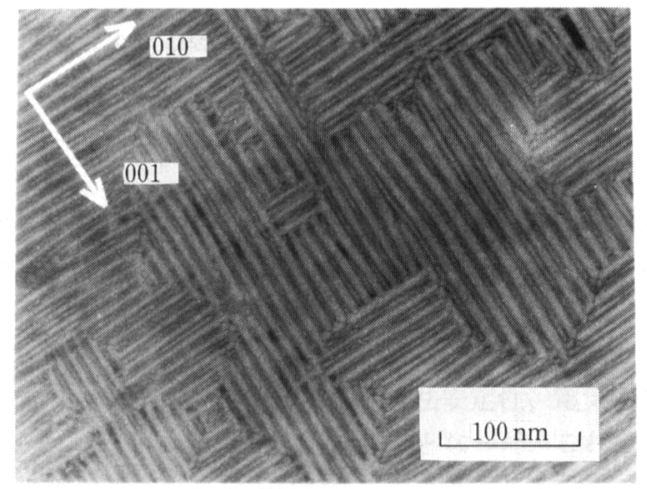

図 $11 \mathrm{Cu}-38.9$ 原子 $\% \mathrm{Zn}$ 合金 $(\beta-$ Brass $)$ の相分離 の透過電顕写真 ${ }^{(24)}$.

歪みがスピノーダル分解に伴って生ずる歪であって, こ れから配列の歪エネルギーをきちんと計算すれば $\boldsymbol{k}(q)$ $=(000)$ で $[001]$ 方向の acoustic モードの歪エネルギー 固有值 $\Delta Z(-)=12.7 \times 10^{-21} \mathrm{~J} /$ atom と一致する筈で ある.ところが, 歪みは対角線 OM あるいは $\mathrm{ON}$ を含 みかつ紙面に垂直な面上でのわずかなずりによっても到

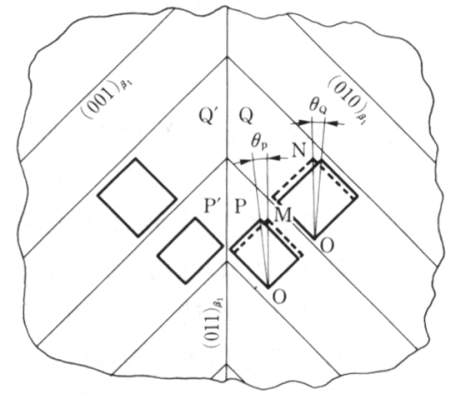

図 $12 \beta$-Brassに打ける相分離に伴うポアソン歪 の定性的説明図. 歪は $\{110\}<1 \overline{1} 0>$ シアー により説明される。

達できる， $\beta$-Brass の場合, 幸いこのずりに対する抵 抗は非常に小さく結晶は容易に図 12 に示す様な正方晶 へと変化し得る. それは TA2フォノンモードが全体に 小さな振動数を持つ事, 言い換えれば $\{110\}$ 面の $\langle 1 \overline{1} 0\rangle$ 方向へのずりに対するバネ定数が異様に小さい事から明 白である。乙こでは詳しく述べないが $|\boldsymbol{k}(q)|$ が小さな 值を持つと仮定して $\Phi_{\mathrm{ij}}$ 亿含まれている exponential の項を展開するといわゆる長波長の関係が求まる(19). それによれば上記の TA2 モードの振動に対するバネ定 数は, 弾性定数の $C_{11}-C_{12}$ に比例しているが, 確かに $C_{11}-C_{12}$ は一般の弾性定数より 1 桁小さく $0,17 \times 10^{9} \mathrm{~N} / \mathrm{m}$ $\left(0.17 \times 10^{12} \mathrm{dyn} / \mathrm{cm}\right)$ となっている．逆に言えば $C_{11}-C_{12}$ の值が小さいと<001>方向に分解しても歪エネルギー が小さくて済むので勢いその方向に分解する事になる.

一方, 格子振動に起因する X 線の散漫散乱(TDS)は $\nu^{-2}$ に比例するので, $\nu$ が小さな值を持てばそれだけ強 度が強いという事になる。図 11 はその結果であるが上 記の様にバネ定数(力の定数) $\rightleftarrows \nu \rightleftarrows$ 散漫散乱と結びつ いている事がよく分かる。ちなみに同じ理由でく110> 方向に強い散漫散乱(TDS) 示す B2 型構造は低温で長 周期の熱弾性型マルテンサイト变態を起し易い.

\section{5. あと がき}

本稿では規則相の相分離として最も簡単な $\beta$-Brass のスピノーダル分解を例にとって分解に伴う歪エネルギー の計算方法および微視的な意味について説明した。微視 的理論の中心課題は Dynamical matrix の構成, すな わち力の定数を求める事である. 力の定数は純金属でも 計算によって正しく求めるためには相当な努力が必要で あり，その中には遷移金属の問題や多体効果の問題等か なり困難な課題を含んでいる。まして合金では定量的に 正しい值を計算によって求める事は不可能である. 従っ て本文に記した様にパラメーターは実験的に求められる のが常である.例えば非弾性中性子線回折を行なって求 めたパラメータを用いて $\beta$ - Brass と同様な計算が $\mathrm{Au}-$ 
Ni 合金について行われている(30)(31).

本文では歪エネルギーだけをしかもスピノーダル分解 に伴うそれのみを解説した。本来ならば析出や相転移む 含み，より本質的な Kineticsにも触れておくべきであっ たが著者の力量不足で触れることができなかった。微視 的理論では孤立した析出物を扱うには析出物の形状を反 映した (フーリエ変換した $) Q(\gamma \mid q)$ が逆格子空間内で, よ゙の程度の拡がりと大きさを持つかを知らなくてはなら ない. 従ってその様な問題は多くの場合, 逆空間に渡る 積分を含む事になるが本文で述べた $\Delta Z\left(\gamma, \gamma^{\prime} \mid q\right)$ さえ $q$ の関数として分かっていればさして困難な問題とはなら ない. 本文で析出や相転移が相分離の応用であるといっ たのはその様な意味においてである．析出や相転移に伴っ て発生する歪や歪エネルギーについては優れた参考書が あるのでそちらを参照されたい(3)(7)(29).

最後に本稿を書くにあたり, 研究室の諸氏, 特に佐藤 豊彦氏には整図の面でお世話になった事を申し述べて感 謝の意を表したい.

\section{文献}

( 1 ) J.W.Cahn : Acta Met., 9(1961), 795.

( 2 ) J.D.Eshelby : Progress in Solid Mechanics, 2, Ed. by I.Sneddon and R.Hill, North-Holland, Amsterdam, (1961), 89.

（3）村 外志夫, 森勉: マイクロメカニックス, 培風館, (1976).

（4）梶谷 剛: 日本金属学会会報, 18(1979), 731.

( 5 ) A.G.Khachaturyan : Progress in Materials Science, Ed. by B.Chalmers, J.W.Christian and T.B.Massalski, Pergamon, New York, (1979), 1.
(6) H.Kubo: J. Phys. Chem. Solid, 30(1983), 323; Phys. Rev. B, 32(1985), 4687.

（7）一般的解説書としては, D.de Fontaine : Solid State Phys., Ed by D.Turnbul and B.Chalmers, 34(1979), 73

( 8 ) H.E.Cook : Acta Met., 23(1975), 1027; 23(1975), 1041.

( 9 ) M.Suezawa ; Trans. JIM, 19(1978), 459.

(10) S.M.Allen and J.W.Cahn : Acta Met., 20(1972), 423 ; 23 (1975), 1017 ; 24(1976), 425.

(11) H.Ino: Acta Met., 26(1978), 827.

(12) V.Paider: Phys. Status Solidi A, 21(1974), K 73.

(13) V.Paider: Czech. J. Phys. B, 27(1977), 50.

(14) P. Coulomb : J. Microsc. Spectrosc. Electron., 2(1977), 389.

(15) M. Bouchard and G. Thomas : Acta Met., 23(1975), 1585.

(16) R.Yokota : J. Phys. Soc. Japan, 45(1978), 1.

(17) F.F.Abraham : J.Chem. Phys., 63(1975), 157, 1316, 2660.

(18) H.E.Cook and D.de Fontaine: Acta Met., 17(1969), 915.

(19) M.Born and K.Huang: Dynamical Theory of Crystal Lattices, Oxford University Press, Oxford, (1954).

(20) 戸谷富之: 日本物理学会誌, 22(1967), 341.

(21) W.A.Harrison : Phys. Rev., 136(1964), A1107, 382, 430, 435.

(22) S.C.Moss : J. Appl. Phys., 35(1964), 3547.

(23) G.Inden : Z.Metallk., 66(1975), 648.

(24) H.Kubo, I.Cornelis and C.M.Wayman : Acta Met., 28 (1980), 405.

(25) H.Kubo and C.M.Wayman : Met. Trans., 10A (1979), 633.

(26) G.Gilat and G.Dolling : Phys. Rev., 138(1965), A 1053.

(27) H.Kubo: Trans. JIM, 23(1982), 655.

(28) H.Cook : J. Phys. Chem. Solids, 30(1969), 1097

(29) A.G.Khachaturyan : Theory of Structural Transformations in Solids, John Wiley \& Sons, New York, (1983).

(30) T.B.Wu, J.B.Cohen and W.Yelon; Acta Met., 30(1982), 2065.

(31) T.B.Wu; Proceedings of the International Conference on Phase Transformations, AIME, held at Crete, Greece, (1986), pp.1. 